\title{
The Development of Scaffolding Aided Learning Tools Using 5E Learning Cycle Model
}

\section{R. P. Sartika ${ }^{1^{*}}$, E. Enawaty ${ }^{2}$, I. Lestari ${ }^{3}$}

1,2,3 Jurusan P.MIPA, Universitas Tanjungpura, Pontianak

e-mail: rodyputrasartika@fkip.untan.ac.id, enawaty@yahoo.co.id, ira.lestari@chem.edu.untan.ac.id

\begin{abstract}
Learning tools have important role to promote effective learning process. Available learning tools was still unable to construct good understanding for students especially in acid base topic. The aims of this study were to examine validity and application of tools and to describe improvement of students conceptual understanding before and after tools applied during learning process. Dick and Carey model was applied as research method. Data were collected by means of interview, observation, and test. Data were analyzed through descriptive qualitative analysis. According to data analysis, validity of lesson plan, worksheet, hand book and evaluation tools were 90,95\%, 90,59\%, 92,16\%, and 97,14\% respectively which categorized as very valid. The application of learning tools was $92,16 \%$ which categorized as very good. The improvement of students conceptual understanding was 0,57 which categorized as average. This research provides learning tools that enhance students conceptual understanding of the concept of acid-base topic.
\end{abstract}

Keywords: Development, 5E Learning Cycle, Scaffolding.

\section{Introduction}

Students know chemistry for its difficulties due to abstract and complex concepts (Yohana et al., 2018). According to Sunyono \& Meristin, (2019), students assume that learning chemistry is complicated. Therefore, students grow antipathy and regard chemistry as a scary subject.

Some research finds that difficulties students face during learning chemistry are the difficulty in understanding Bronsted-Lowry acid-base theory after learning Arrhenius acid-base theory (Kim et al., 2019), difficulty in differentiating between strong and weak acid-base (Yohana et al., 2018), difficulty in writing and balancing sulfuric acid and natrium hydroxide equation, difficulty in determining the concentration of monovalent and bivalent acids (Tri Astuti \& Marzuki, 2018). The problems of acid-base concepts have also occurred among students of the chemistry education program of Tanjung pura University. The difficulties are as follows: the difficulty in identifying ionized and hydrolysed species; the difficulty in determining the $\mathrm{pH}$ according to conductivity; the difficulty in differentiating strong and weak acids and bases; and the difficulty in determining $\mathrm{pH}$ of solutions.

The difficulties that occur among students are caused by lacking understanding of acidbase concepts. Students are found to fail to understand ionization and equilibrium and their connection to acid-base concepts. Furthermore, students are found to have a poor understanding of mol and concentration concepts. The lack of understanding of abstract and algorithmic concepts has led students to have poor learning achievement. According to (Rahmawati et al., 2019) and (Muflihah et al., 2020), conceptual understanding is important due to the ability to retain concepts and create meaningful learning experiences.

According to interviews with lectures of chemistry education program, the course of basic chemistry is still delivered by lecture, question and answer, and experiment methods. According to (Juniarsih, 2015), good learning is not only the transportation of knowledge from teachers to students but rather allowing students to construct their own knowledge. This learning can be realized through constructivism (Muflihah et al., 2020). Through constructivism, students become active and tend to be more prepared for learning (Pratiwi,

\footnotetext{
${ }^{*}$ Corresponding author.
} 
2016). Furthermore, students will obtain knowledge easier if there is a possibility to discuss (Rapitasari et al., 2017).

One of the constructivism based learning models is the $5 \mathrm{E}$ learning cycle (Shofiah et al., 2018) and (Imran et al., 2019). The 5E learning cycle consists of 5 phases: engagement, exploration, explanation, elaboration, and evaluation (Sari et al., 2016). 5E learning cycle is designed to promote students learning (Pratiwi, 2016). The 5E learning cycle will involve students in active learning since it is a student's-oriented model (Astriani \& Istiqomah, 2016).

$5 \mathrm{E}$ learning cycle gives students opportunities to construct their knowledge through active learning. The strength of the $5 \mathrm{E}$ learning cycle is on students' involvement during learning (Budiman et al., 2019) through active learning, which assimilation, accommodation, and organization of cognitive structure occur (Imran et al., 2019). Some researches show that 5E learning cycle improves students learning achievements (Budiman et al., 2019; Rejeki et al., 2015; Sari et al., 2016), conceptual understanding (Pratiwi, 2016; Sartika, 2018; Sartika \& Lestari, 2016), and critical thinking skills (Hartawati et al., 2020; Latifa et al., 2017; Sartika \& Lestari, 2016).

The implementation of the $5 \mathrm{E}$ learning cycle on chemistry needs learning tools. Therefore, teaching activities occur effectively and efficiently. Since any older learning tools that have already provided tend to place students as receivers, the development is necessary to help students learn. According to Shofiah et al., (2018), teaching tools' development depends on the selection of the learning model. According to Alice \& David, (2018), the learning cycle must be the picture of ideal learning.

The use of scaffolding in this study helps students master prerequisite concepts (Pratama \& Saregar, 2019). Scaffolding is designed to guide students. Scaffolding can be provided by teachers to guide and promote students learning (Zainuddin et al., 2016; Zamahsari et al., 2019). Scaffolding is also used to explore important and complex phenomena and help students solve their problems (Aprian et al., 2017; Sobirin et al., 2018). Some research shows that scaffolding improves student achievement. Research conducted by (Erlin Eveline et al., 2019) stated that the learning process assisted by IPMLM media with the scaffolding approach can help students complete tasks on the HOTS aspect and improve learning with 21 st century learning-based activities. Then the research conducted by (J. C. Y. Sun \& Hsu, 2019) stated that he results suggest that several simultaneous types of scaffolding tend to reduce the effectiveness of the scaffolding systems through media-multitasking. Other research was also conducted by (S. W. Sudarman \& Linuhung, 2017) stated that Scaffolding learning model can improve students' understanding of concepts in mathematics. The availability of scaffolding aided $5 \mathrm{E}$ learning cycle learning tools is expected to help students master acid-base concepts completely by constructing their own knowledge. This study aims to determine the feasibility of the targeted product and to explore the effect of implementing the product on improving student learning achievements.

\section{Method}

This study was research and development study which adopt Dick, Carey, \& Carey steps which are as follows; identifying instructional goals, conducting instructional analysis, analyzing learners and contexts, writing performance objectives, developing assessment instruments, planning the instructional strategy, developing instructional materials, designing and conducting formative assessments and revising instructional materials. Subjects in this study were Lesson plans, worksheets, handbooks, and assessment instruments. These learning tools were tested using one group of pretest-postest design.

The research procedures were as follows: pre-research of student difficulties on acidbase concepts, planning and designing a product using Dick, Carey \& Carey research and development model, validating through cooperative discussions, field testing towards seven students of chemistry department who were studying basic chemistry II, and revising learning tools. Data Collection techniques were indirect communications to examine feasibility, observation technique to examine compliance lesson plans, and measurement technique to determine conceptual understanding improvement. 
Instruments used in this study were validation sheets of lesson plans, learning materials, worksheets, and assessment instruments, observation sheets of lesson plan compliance, and achievement tests. The data analysis technique was qualitative descriptive, which steps were as follows: score tabulations, calculating average scores of all components, and interpretation of scores. Reference criteria for learning tool validations were shown in Table 1, and reference criteria for compliance of lesson plans were shown in Table 2.

The improvements of conceptual understanding were determined through qualitative descriptive analysis which steps were as follows: scoring student achievement test, calculating the improvement of student conceptual understanding through normalized gain formula by Hake in (Nissen et al., 2018).

Note:

$$
g=\frac{\left(\bar{x}_{\text {post }} \bar{x}_{\text {pre }}\right)}{100 \%-\bar{x}_{\text {pre }}}
$$

g = average score of normalized gain.

$\bar{x}_{\text {post }}=$ average score of post test

$\bar{x}_{\text {pre }}=$ average score of pre test.

Table 1. Learning tool validation categories

\begin{tabular}{cc}
\hline Score (\%) & Criteria \\
\hline $80-100$ & Very feasible \\
$66-79$ & Feasible \\
$56-65$ & Moderately feasible \\
$41-55$ & Slightly feasible \\
$0-40$ & Not feasible \\
\hline
\end{tabular}

(Source: Riduan in (Iswara et al., 2020))

Table 2. Lesson plan compliance categories

\begin{tabular}{cc}
\hline Score (\%) & Criteria \\
\hline $80-100$ & Excellent \\
$66-79$ & Very good \\
$56-65$ & Good \\
$41-55$ & Fair \\
$0-40$ & Poor \\
\hline
\end{tabular}

Normalized gain score criteria were classified into three levels, as shown in Table 3.

Table 3. Normalized gain score classification

\begin{tabular}{cc}
\hline Normalized gain & classifications \\
\hline $\mathrm{g}<0,3$ & Poor \\
$0,3 \leq \mathrm{g}<0,7$ & Good \\
$\mathrm{g} \geq 0,7$ & Excellent \\
\hline
\end{tabular}

(Source: Hake in (Nissen et al., 2018))

\section{Result and Discussion} in Table 4.

Three validators did learn tool validations. The result of lesson plan validation is shown 
Table 4. The Result of lesson plan validations.

\begin{tabular}{cccc}
\hline \multirow{2}{*}{ Components } & \multicolumn{3}{c}{ Lesson plan validations } \\
\cline { 2 - 4 } & Validator 1 & Validator 2 & Validator 3 \\
\hline Total & 68 & 58 & 65 \\
Averages & 4,86 & 4,14 & 4,64 \\
Percentages & 97,14 & 82,86 & 92,86 \\
Criteria & Very feasible & Very feasible & Very feasible \\
\hline \multirow{2}{*}{ Validator recommendations } & $\begin{array}{c}\text { Applicable with } \\
\text { little revision }\end{array}$ & $\begin{array}{c}\text { Applicable with } \\
\text { little revision }\end{array}$ & $\begin{array}{c}\text { Applicable with } \\
\text { little revision }\end{array}$ \\
\hline
\end{tabular}

The percentage of average scores from validators is $90,95 \%$, which is categorized as very feasible. According to suggestions from validators during a discussion, there are revisions on lesson plans. They are additions on comment columns, as shown in figure 1. The revision is also located on indicator columns by adding "observed," as shown in figure 2. The percentage of worksheet validations is $90,59 \%$ which is categorized as very feasible (Table 5).



(a)

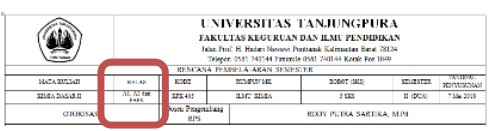

(b)

Figure 1. (a) before, (b) after additions on class of identity column.

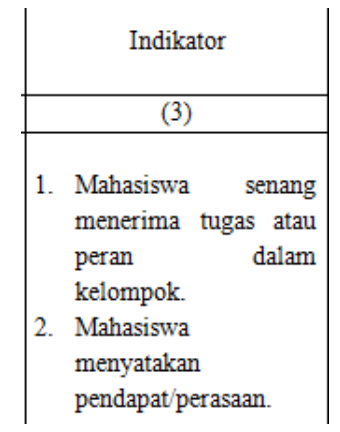

(a)

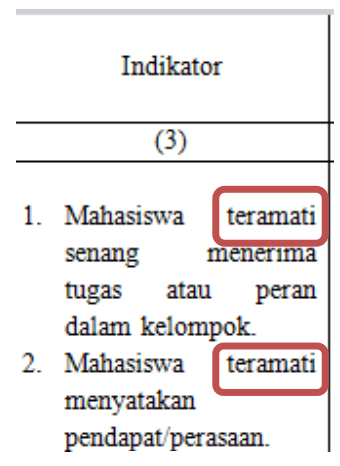

(b)

Figure 2. (a) before (b) after addition of "observed" on affective indicators.

The revisions on worksheets one is located in instructional goals, coloring, sentence writing, and placements. The revision on instructional purposes is done by adding "using universal indicators", as shown in Figure 3.

Table 5. The result of worksheet validations.

\begin{tabular}{cccc}
\hline \multirow{2}{*}{ Components } & \multicolumn{3}{c}{ Worksheet validations } \\
\cline { 2 - 4 } & Validator 1 & Validator 2 & Validator 3 \\
\hline Total & 85 & 68,5 & 77,5 \\
Averages & 5 & 4,03 & 4,56 \\
Percentages & 100 & 80,59 & 91,18 \\
Criteria & Very feasible & Very feasible & Very feasible \\
\hline \multirow{2}{*}{ Validator recommendations } & $\begin{array}{c}\text { Applicable with } \\
\text { little revision }\end{array}$ & $\begin{array}{c}\text { Applicable with } \\
\text { little revision }\end{array}$ & $\begin{array}{c}\text { Applicable with } \\
\text { little revision }\end{array}$ \\
\hline
\end{tabular}




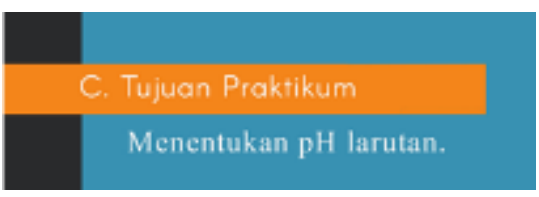

(a)

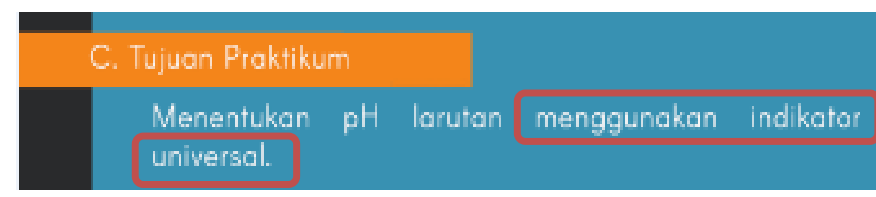

(b)

Figure 3. (a) before (b) after addition of "using universal indicators" on instructional goals.

The revision on coloring is done by erasing white colour on background on related changes of indicator colours, as shown in Figure 4. The revisions of incorrect words/sentences are shown in Figure 5. The placements are to adjust materials on every page, as shown in Figure 6 . The revisions on the worksheet two are done by changing colours, especially on the first page, which replaces background colour from black into white, as shown in Figure 7 . The revisions on handbooks are in fitness between concepts and indicators, the context of sentences, picture selections, and front cover layout. The result of the handbooks is shown in Table 6.

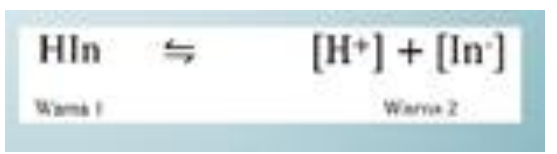

(a)

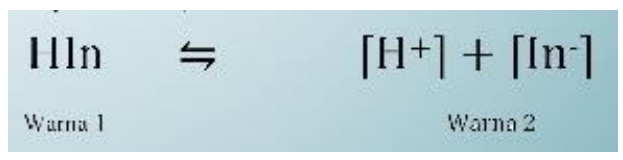

(b)

Figure 4. (a) before (b) after changing of white background colour on reaction equations.

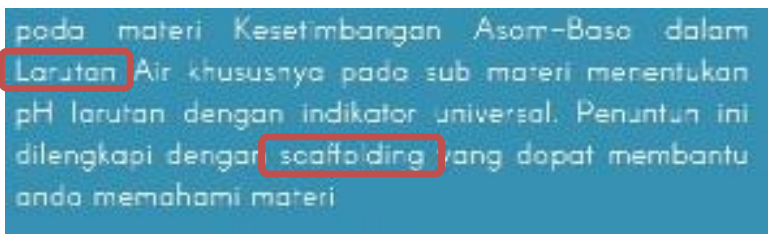

(a)



(b)

Figure 5. (a) before (b) after revisions on words/sentences.

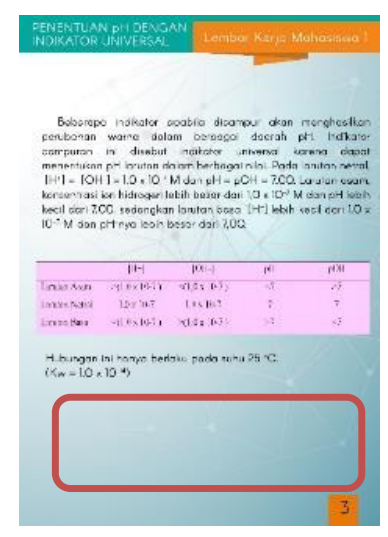

(a)

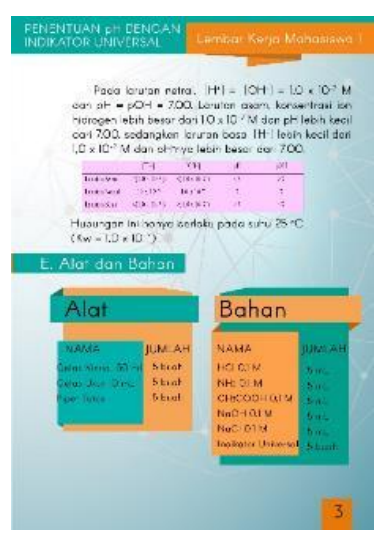

(b)

Figure 6. (a) before (b) after changing the placements on worksheet 1 . 


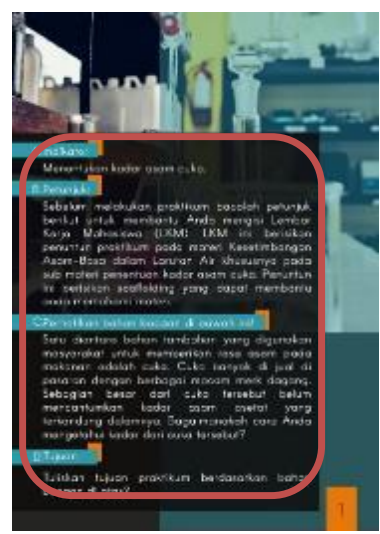

(a)

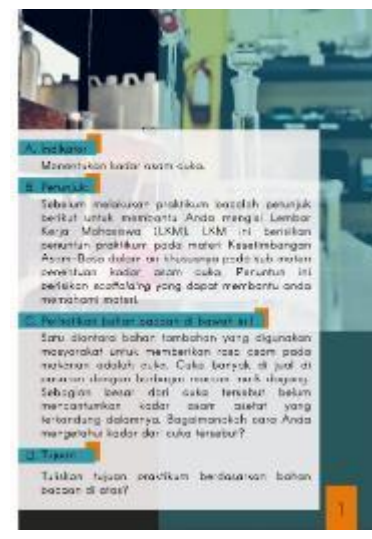

(b)

Figure 7. (a) before, (b) after changing colours on background colour of first page on worksheet 2 .

Table 6. The result of handbook validations.

\begin{tabular}{|c|c|c|c|}
\hline \multirow{2}{*}{ Components } & \multicolumn{3}{|c|}{ Handbook validations } \\
\hline & Validator 1 & Validator 2 & Validator 3 \\
\hline Total & 85 & 68 & 82 \\
\hline Averages & 5 & 4 & 4,82 \\
\hline Percentages & 100 & 80 & 96,47 \\
\hline Criteria & Very feasible & Very feasible & Very feasible \\
\hline Validator recommendations & $\begin{array}{l}\text { Applicable with } \\
\text { little revision }\end{array}$ & $\begin{array}{l}\text { Applicable with } \\
\text { little revision }\end{array}$ & $\begin{array}{l}\text { Applicable with } \\
\text { little revision }\end{array}$ \\
\hline
\end{tabular}

According to Table 6 , the average score is $92,16 \%$, which is categorized as very feasible. The revisions are additions of scaffoldings on the topic of weak acid-base pH (Figure 8). The additions of scaffoldings are expected to help students to achieve instructional goals. The revisions on sentence contexts are in the topic of acid-base theories by adding "ions" and "in water", as shown in Figure 9. The revisions on picture selections are additions of phases of $5 \mathrm{E}$ learning cycle in cover layout. These revisions are shown in Figure 10.

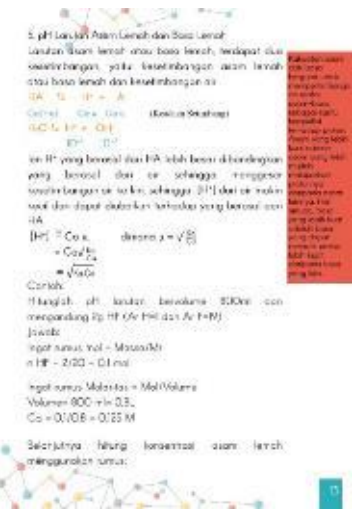

(a)

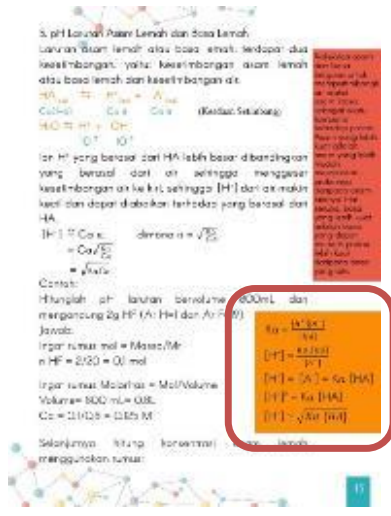

(b)

Figure 8. (a) before, (b) after additions of scaffoldings on topic of weak acid base. 


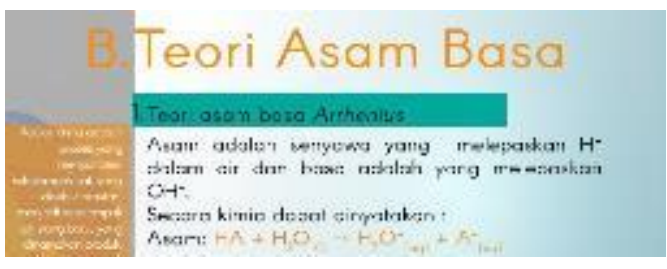

(a)

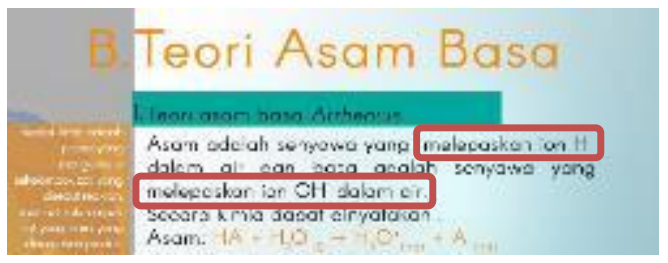

(b)

Figure 9. (a) before and (b) after additions of "ions" and "in aqueous solution".

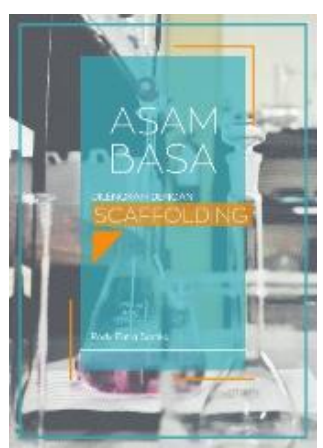

(a)

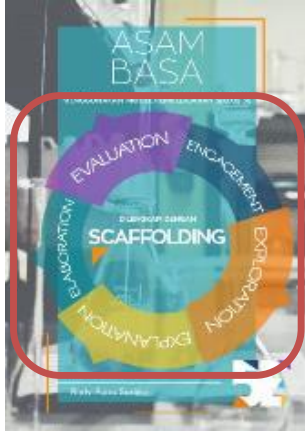

(b)

Figure 10. (a) before, and (b) after additions of phases of $5 \mathrm{E}$ learning cycle on cover layout.

Table 7. The result of achievement test validations.

\begin{tabular}{|c|c|c|c|}
\hline \multirow{2}{*}{ Components } & \multicolumn{3}{|c|}{ Validations of achievement tests } \\
\hline & Validator 1 & Validator 2 & Validator 3 \\
\hline Total & 60 & 55 & 60 \\
\hline Averages & 5 & 4,57 & 5 \\
\hline Percentages & 100 & 91,43 & 100 \\
\hline Criteria & Very feasible & Very feasible & Very feasible \\
\hline Validator recommendations & $\begin{array}{l}\text { Applicable with } \\
\text { little revision }\end{array}$ & $\begin{array}{l}\text { Applicable with } \\
\text { little revision }\end{array}$ & $\begin{array}{l}\text { Applicable with } \\
\text { little revision }\end{array}$ \\
\hline
\end{tabular}

The result of achievement test validations is shown in table 7 . The percentage of the average score is $97,14 \%$, which is categorized as very feasible. The revisions are replacements of grammatically incorrect sentences (Figure 11) and unrelated sentences towards indicators and measured behaviors (Figure 12).

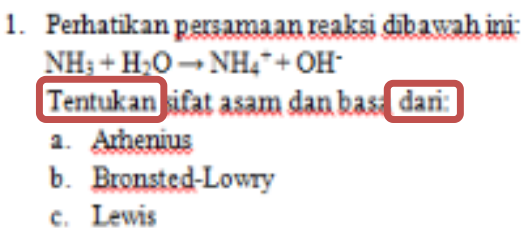

(a)

\section{Perhatikan persamaan reaksi dibawah ini- $\mathrm{NH}_{3}+\mathrm{H}_{2} \mathrm{O} \rightarrow \mathrm{NH}_{4}^{+}+\mathrm{OH}^{-}$ Jelaskan sifat asam dan basa berdasarkan:
a. Axhenius
b. Bronsted-Lowry \\ c. Lewis}

(b)

Figure 11. (a) before, and (b) after revisions of sentences on questions thus showing fitness between indicators-questions

After validation processes, the next step is to conduct an initial field test that involves seven students of the chemistry education program of Tanjungpura University. The initial field 
test is done by implementing scaffolding aided learning tools on learning through the $5 \mathrm{E}$ learning cycle model. The average score of compliance of lesson plans is $92,16 \%$ which is categorized as excellent as shown in Table 8.

Table 8. The measurement of lesson plan compliances during initial field test

\begin{tabular}{cccc}
\hline \multirow{2}{*}{ Components } & \multicolumn{3}{c}{ Measurement } \\
\cline { 2 - 4 } & Observer 1 & Observer 2 & Observer 3 \\
\hline Total & 53 & 45 & 57 \\
Averages & 4,42 & 3,75 & 4,75 \\
Percentages & 88,33 & 75 & 95 \\
\hline Criteria & Excellent & Good & Excellent \\
\hline
\end{tabular}

According to observations, there remain obstacles to compliance with lesson plans, especially during the elaboration phase. In this phase, students encounter difficulties completing tasks in worksheet two in the topic of calculations of acetic acid concentrations. Students are confused about using formulas to calculate concentrations. Thus, this phase takes a long time to do. The suggestions are made by simplifying formulas and give an extra example of solving problems as shown in Figure 13

The effectiveness of learning tools can be measured by comparing student achievements before and after treatment given. The improvements of student achievements are shown in Table 6 . The average score of improvements after learning with learning tools through scaffolding aided $5 \mathrm{E}$ learning cycle model is 0,57 which is categorized as good (Table 9).

3. Salah satu basa kuat $\mathrm{Ca}(\mathrm{OH})_{2}$ biasa digunakan sebagai pengatur $\mathrm{pH}$ air limbah dan juga sebagai sumber basa yang harganya relatif murah. Berapakah pH dari larutan $\mathrm{Ca} / \mathrm{OH}>0.01 \mathrm{M}$ !

(a)

3. $\mathrm{Ca}(\mathrm{OH})_{2}$ menupakan satu diantara basa kuat yang biasa digunakan sebagai pengatur $\mathrm{pH}$ air limbah dan juga sebagai sumber basa yang harganya relatif murah. Beranakah pH dari lantan $\mathrm{Ca}(\mathrm{OH}$ ) $0,01 \mathrm{M}$ !

(b)

Figure 12. (a) before, (b) after revisions of sentences thus showing correct grammar.

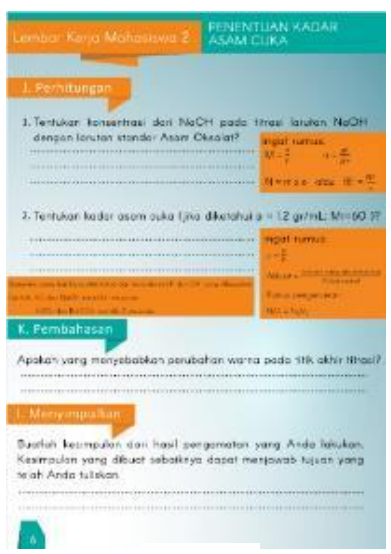

(a)

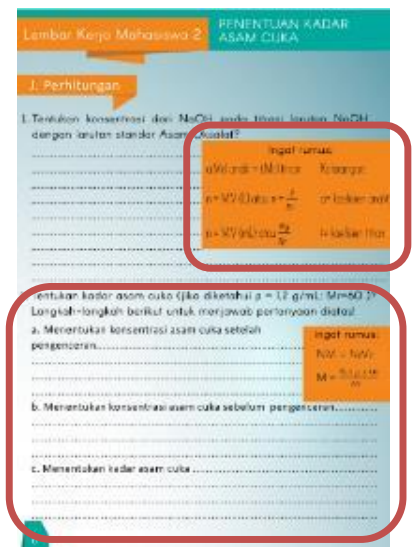

(b)

Figure 13. (a) before (b) after simplifying of formulas and additions of problems solving 
Table 9. The improvements of conceptual understanding after treatment given

\begin{tabular}{|c|c|c|c|c|}
\hline Codes & $\begin{array}{l}\text { Pretest } \\
\text { Scores }\end{array}$ & $\begin{array}{c}\text { Posttest } \\
\text { Scores }\end{array}$ & N-Gain & Improvement criteria \\
\hline UA1 & 39,39 & 61,62 & 0,37 & Good \\
\hline UA2 & 17,17 & 43,43 & 0,32 & Good \\
\hline UA3 & 18,18 & 32,32 & 0,17 & Poor \\
\hline UA4 & 44,44 & 46,46 & 0,04 & Poor \\
\hline UA5 & 18,18 & 27,27 & 0,11 & Poor \\
\hline UA6 & 71,72 & 87,88 & 0,57 & Good \\
\hline UA7 & 39,39 & 63,64 & 0,40 & Good \\
\hline
\end{tabular}

The improvements of conceptual understanding of acid-base concepts occur to every student (Table 9) after learning with tools developed through scaffolding aided 5E learning cycle model. Learning through the $5 \mathrm{E}$ learning cycle model consists of 5 phases: engagement, exploration, explanation, elaboration, and evaluation. According to (Pratiwi, 2016), the 5E learning cycle model guides students to construct their own knowledge. The $5 \mathrm{E}$ learning model involves students to explore for constructing knowledge (Sari et al., 2016). According to (Armansyah et al., 2018), the 5E learning cycle model facilitates students actively learning activities such as doing experiments, giving opinions, and asking questions. $5 \mathrm{E}$ learning cycle model with discussions and experiments helps to active (Yuliana et al., 2020).

The engagement phase starts by asking definitions of acid and base and explaining the advantages of acids and bases for our daily lives by detecting any existing misconceptions. This phase aims to prepare students to follow the next phase by exploring their previous knowledge (Latifa et al., 2017). Student enthusiasm will increase by adding related phenomena (Putra et al., 2018).

The exploration phase starts by giving opportunities to students to construct knowledge through the experiment of determining the $\mathrm{pH}$ of acid-base solutions by the guidance of handbooks and worksheets. According to Latifa et al., (2017), in this phase, students are given opportunities to work in groups to do activities such as doing experiments and reviewing the literature. During this phase, students learn meaningfully, practice, and develop scientific attitudes (Suardana et al., 2018). Students explore their materials to prove their opinions (Putra et al., 2018). According to (Sari et al., 2016), in engagement and exploration phases, students are asked to connect concepts to their daily life contexts to grow interested.

Scaffolding in this study is given during the exploration phase provided in handbooks and worksheet 1 (determining the $\mathrm{pH}$ of aqueous solutions). The examples of scaffolding are shown in Figures 8b and 13b. According to (Zamahsari et al., 2019), scaffolding will help students to solve questions by giving them guidance (Zainuddin et al., 2016). Scaffolding will ease students in understanding concepts (Pratama \& Saregar, 2019). According to (Sobirin et al., 2018), scaffolding successfully motivates and supports students to plan and implement a strategy to gain knowledge. Scaffolding is guidance for a better learning experience, especially during the early phase of the learning process (Masnia \& Zubaidah Amir, 2019).

The implementation of the $5 \mathrm{E}$ learning cycle is done in big groups. Therefore, students are able to help others to understand acid-base concepts. According to (Rapitasari et al., 2017), constructivism applies cooperative learning intensively. Thus, students are allowed to discuss complex concepts. Furthermore, students need to learn according to the Zone of Proximal development to interact with them (Aprian et al., 2017).

The explanation phase starts by giving students opportunities to present their work in front of the class to measure their learning achievements. According to Latifa et al., (2017), in this phase, students share their thoughts by their own words. Teachers encourage students to explain concepts by giving evidence (Ilmi et al., 2019). Moreover, during this phase, there occurs in information sharing about concepts (Sari et al., 2016). According to (Kazempour et al., 2020), teacher roles are provided with references and facilitation for discussions. 
In the elaboration phase, students conduct advanced experiments by the guidance of worksheet 2 to determine acetic acid concentrations. This activity is carried out to expand concepts found in previous phases. During this phase, students develop concepts and skills in new situations (Latifa et al., 2017). This phase is intended to give students opportunities to apply their knowledge to solve new problems (Suardana et al., 2018). Teachers should provide learning activities that allow authentic experiences (Putra et al., 2018). Connecting concepts with authentic examples of daily life will make concepts useful and meaningful (Sari et al., 2016).

Evaluation is the last phase which starts by asking questions to students to examine their learning achievements. During this phase, teachers assess whether students have successfully achieved instructional goals (Latifa et al., 2017). This phase is intended to give formative evaluations (Suardana et al., 2018). Some research shows that scaffolding improves student achievement. Research conducted by (Erlin Eveline et al., 2019) stated that the learning process assisted by IPMLM media with the scaffolding approach can help students complete tasks on the HOTS aspect and improve learning with 21 st century learning-based activities. Then the research conducted by (Jerry Chih Yuan Sun \& Hsu, 2019) stated that he results suggest that several simultaneous types of scaffolding tend to reduce the effectiveness of the scaffolding systems through media-multitasking. Other research was also conducted by (Satrio Wicaksono Sudarman \& Linuhung, 2017) stated that Scaffolding learning model can improve students' understanding of concepts in mathematics.

This study has developed learning tools (lesson plans, handbooks, worksheets, and instruments of measurements) through the implementation of scaffolding aided $5 \mathrm{E}$ learning cycle model, which is categorized as very feasible as shown in Tables 4,5, 6, and 7 . Furthermore, the compliance of the lesson plan is categorized as good. The learning tools help students to construct concepts and promote active learning. These achievements are shown from the improvements in student learning achievements, which are categorized as good (Table 9). This result is in line with (Sartika \& Ariansyah, 2019) which show the achievements of development through 5E learning cycle. Research conducted by (Murnaka \& Yuniarti, 2018) (Murnaka \& Yuniarti, 2018) stated that the improvement of math- lemmatical communication ability of students who get learning cycle $5 \mathrm{e}$ model is higher than students who get conventional learning.

\section{Conclusions and recommendations}

In conclusion, the feasibility of lesson plans, worksheets, handbooks, and instruments of assessment is categorized as very feasible. The improvement of conceptual understanding is categorized as good. The recommendations are providing longer duration for guiding intensively during initial field tests (especially in the elaboration phase) because students are found confused in applying and developing concepts.

\section{Acknowledgement} research.

Appreciation for the dean of FKIP Tanjungpura University who facilitates and funds this

\section{References}

Alice, K., \& David, K. (2018). Eight Important Things to Know About The Experiential Learning Cycle. Australian Educational Leader, 40(3), 8-14.

Aprian, R. D., Sunyono, \& Efkar, T. (2017). Pengaruh Strategi Scaffolding pada Pembelajaran SiMaYang dalam Meningkatkan Keterampilan Proses Sains. Jurnal Pendidikan Dan Pembelajaran Kimia, 6(1), $1-13$. https://doi.org/http://jurnal.fkip.unila.ac.id/index.php/JPK/article/view/12799

Armansyah, A., Ibrahim, M., \& Wasis, W. (2018). Pengembangan Perangkat Pembelajaran Fisika Menggunakan Model Siklus Belajar 5E untuk Melatihkan Kemampuan Berpikir Kritis. Prisma Sains : Jurnal Pengkajian IImu Dan Pembelajaran Matematika Dan IPA IKIP Mataram, 6(2), 56. https://doi.org/10.33394/j-ps.v6i2.967 
Astriani, D., \& Istiqomah, N. N. (2016). Model Pembelajaran Learning Cycle 5E: Mengaktifkan Siswa Pada Materi Suhu dan Perubahannya. Jurnal Penelitian Pendidikan IPA, 1(2), 71-75. https://doi.org/https://journal.unesa.ac.id/index.php/jppipa/article/view/1746

Budiman, R., Muchlis, \& Rusdi Efrida, E. (2019). Penerapan Model Pembelajaran Learning Cycle 5E Untuk Meningkatkan Hasil Belajar Matematika Siswa Kelas VIII SMPN 15 Kota Bengkulu. Jurnal Penelitian Pembelajaran Matematika Sekolah (JP2MS), 3(2), 218-227. https://doi.org/10.33369/jp2ms.3.2.218-227

Erlin Eveline, Suparno, S., Ardiyati, T. K., \& Dasilva, B. E. (2019). Development of Interactive Physics Mobile Learning Media for Enhancing Students' HOTS in Impulse and Momentum with Scaffolding Learning Approach. Jurnal Penelitian \& Pengembangan Pendidikan Fisika, 5(2), 123-132. https://doi.org/10.21009/1.05207

Hartawati, Y., Harjono, A., \& Verawati, N. N. S. P. (2020). Kemampuan Berpikir Kritis Momentum Dan Impuls Ditinjau Dari Gaya Belajar Peserta Didik Dengan Model Learning Cycle 5E. ORBITA: Jurnal Kajian, Inovasi Dan Aplikasi Pendidikan Fisika, 6(1), 181. https://doi.org/10.31764/orbita.v6i1.1515

IImi, N., Salempa, P., \& Side, S. (2019). Penerapan Model Pembelajaran Learning Cycle 5 E y ang Terintegrasi dengan Metode Problem Solving The Application of Learning Cycle 5E Model which was Integrated with Problem Solving Method. Jurnal Sainsmat, 8(2), 36-46. https://doi.org/https://ojs.unm.ac.id/sainsmat/article/view/10718/0

Imran, A., Amini, R., \& Aliasar. (2019). The development of Science learning module use the Learning Cycle 5E for Elementary School student. 3(Global Conferences Series: Social Sciences, Education and Humanities (GCSSSEH), 3, 175-180. https://doi.org/https://series.gci.or.id/article/206/13/icesshum-2019

Iswara, G. P., Kuswandi, D., \& Husna, A. (2020). Pengembangan Multimedia Interaktif Dilengkapi Dengan Simulasi Untuk Memvisualisasikan Reaksi Kimia Pada Materi Larutan Penyangga SMA Kelas XI. JINOTEP (Jurnal Inovasi Teknologi Pembelajaran), 58-68.

Juniarsih, Q. A. (2015). Peningkatan Retensi Belajar Materi Klasifikasi Makhluk Hidup Melalui Penerapan Discovery Leraning dan Team Games Tournament pada Siswa Kelas VIIG SMP NEGERI 18 Malang. Prosiding Seminar Nasional Pendidikan Biologi, 157-167.

Kazempour, M., Amirshokoohi, A., \& Blamey, K. (2020). Putting theory to practice: Teaching the $5 \mathrm{E}$ learning cycle through immersive experiences for pre-service teachers. European Journal of Science and Mathematics Education, 8(1), 67-75. https://doi.org/https://eric.ed.gov/?id=EJ1242141

Kim, S., Choi, H., \& Paik, S. H. (2019). Using a Systems Thinking Approach and a Scratch Computer Program to Improve Students' Understanding of the Brønsted-Lowry AcidBase Model. Journal of Chemical Education, 96(12), 2926-2936. https://doi.org/https://pubs.acs.org/doi/abs/10.1021/acs.jchemed.9b00210

Latifa, B. R. A., Verawati, N. N. S. P., \& Harjono, A. (2017). Pengaruh Model Learning Cycle 5E (Engage, Explore, Explain, Elaboration, \& Evaluate) Terhadap Kemampuan Berpikir Kritis Peserta Didik Kelas X Man 1 Mataram. Jurnal Pendidikan Fisika Dan Teknologi, 3(1), 61. https://doi.org/http://jurnalfkip.unram.ac.id/index.php/JPFT/article/view/325

Masnia, F., \& Zubaidah Amir, M. (2019). Pengaruh Penerapan Model Scaffolding terhadap Kemampuan Pemahaman Konsep Matematis Berdasarkan SElf Efficacy Siswa SMP. Juring(Journal for Research in Mathematics Learning), 2(3), 249- 256. https://doi.org/10.24014/juring.v2i3.7675

Muflihah, Supardi, K. I., \& Sumarni, W. (2020). Concept Understanding Analysis of Coloid Materials After Application of Joyful Learning Problem Based Learning. JISE, 9(3), 306 - 313. https://doi.org/10.15294/JISE.V9l1.36713 
Murnaka, N. P., \& Yuniarti, N. (2018). Efektifitas Model Pembelajaran Learning Cycle 5e Terhadap Kemampuan Komunikasi Matematis Siswa Kelas VII. Kreano Jurnal Matematika Kreatif-Inovatif, 9(1), 28-37. https://doi.org/https://doi.org/10.15294/kreano.v9i1.10957

Nissen, J. M., Talbot, R. M., Thompson, A. N., \& Van Dusen, B. (2018). A comparison of normalized gain and Cohen's d for analyzing gains on concept inventories. Physical Review Physics Education Research, 14(1). https://doi.org/10.1103/PhysRevPhysEducRes.14.010115

Pratama, R. A., \& Saregar, A. (2019). Pengembangan Lembar Kerja Peserta Didik (LKPD) Berbasis Scaffolding Untuk Melatih Pemahaman Konsep. Indonesian Journal of Science and Mathematics Education, 2(1), 84-97. https://doi.org/10.24042/ijsme.v2i1.3975

Pratiwi, D. D. (2016). Pembelajaran Learning Cycle 5e berbantuan GeoGebra terhadap Kemampuan Pemahaman Konsep Matematis. Al-Jabar: Jurnal Pendidikan Matematika, 7(9), 191-202. https://doi.org/10.24042/ajpm.v7i2.34

Putra, F., Nur Kholifah, I. Y., Subali, B., \& Rusilowati, A. (2018). 5E-Learning Cycle Strategy: Increasing Conceptual Understanding and Learning Motivation. Jurnal IImiah $\begin{array}{llll}\text { Pendidikan Fisika } & \text { Al-Biruni, } & 7(2), & \end{array}$ https://doi.org/https://pdfs.semanticscholar.org/1f6d/b0ec17573220b4de7b10c70c145 602d2e3e3.pdf

Rahmawati, A. P., Aisyah, R. S., \& Afiffah, I. (2019). Penerapan Model Pembelajaran POGIL Sebagai Upaya Meningkatkan Pemahaman Konsep Larutan Penyangga. EduChemia, 4(1), 58-68. https://doi.org/10.30870/educhemia.v4i1.4846

Rapitasari, D., Herawaty, D., \& Yensy, N. A. (2017). Upaya Meningkatkan Hasil Belajar Matematika Siswa Kelas Viii Melalui Pendekatan Konstruktivisme Pada Materi Bangun Ruang Sisi Datar. Jurnal Penelitian Pembelajaran Matematika Sekolah (JP2MS, 1(1), 87-93. https://doi.org/10.33369/jp2ms.1.1.87-93

Rejeki, D. P., Hasan, M., \& Haji, A. G. (2015). Penerapan Model Pembelajaran Learning Cycle 5E pada Materi Kelarutan dan Hasil Kali Kelarutan untuk Meningkatkan Hasil Belajar dan Sikap Peserta Didik SMAN 1 Krueng Barona Jaya. Jurnal Pendidikan Sains Indonesia, 3(1),

19-26. https://doi.org/http://www.jurnal.unsyiah.ac.id/JPSI/article/view/7646

Sari, I. N., Saputri, D. F., \& Beno, Y. (2016). Penerapan Model Learning Cycle 5E dalam Materi Besaran Pokok dan Turunan di Kelas VII SMP Negeri 1 Sengah Temila. Urnal IImiah Pendidikan Fisika Al-BiRuNi, 5(2), 277-282. https://doi.org/10.24042/jpifalbiruni.v5i2.127

Sartika, R. P. (2018). Peranan Model Siklus Belajar 5E dalam Meningkatkan Pemahaman Konsep Sifat Koligatif Larutan. EduChemia, 3(2), 157-171. https://doi.org/10.30870/educhemia.v3i2.3052

Sartika, R. P., \& Ariansyah, D. (2019). Pengembangan Perangkat Pembelajaran Menggunakan Model Siklus Belajar 5E Berbantuan Strategi PQ4R Pada Materi Hidrolisis Garam. Seminar Nasional Pendidikan Fakultas Keguruan Dan IImu Pendidikan Universitas Tanjungpura Tahun 2019, 413-423.

Sartika, R. P., \& Lestari, I. (2016). Peningkatan Pemahaman Siswa pada Materi Koloid menggunakan Pembelajaran Model Siklus Belajar 5E Kelas XI SMAN 2 Pontianak. Jurnal Pendidikan Matematika Dan IPA, 7(2), 41-50. https://doi.org/10.30870/educhemia.v3i2.3052

Shofiah, S., Lukito, A., \& Siswono, T. Y. (2018). Pembelajaran Learning Cycle 5E Berbasis Pengajuan Masalah untuk Meningkatkan Hasil Belajar Siswa Kelas X pada Topik 
Trigonometri. Kreano, 9(1), 54-62. https://doi.org/10.15294/kreano.v9i1.9856

Sobirin, M., H, S. K., \& Kusairi, S. (2018). Distributed Scaffolding on Inquiry Learning towards Hig. 6(4), 128-134.

Suardana, I. N., Redhana, I. W., Sudiatmika, A. A. I. A. R., \& Selamat, I. N. (2018). Students' critical thinking skills in chemistry learning using local culture-based 7E learning cycle model. International Journal of Instruction, 11(2), 399-412. https://doi.org/https://eric.ed.gov/?id=EJ1174908

Sudarman, S. W., \& Linuhung, N. (2017). Pengaruh Pembelajaran Scafolding Terhadap Pemahaman Konsep Integral Mahasiswa. Aksioma Journal of Mathematics Education, 6(1). https://doi.org/10.24127/ajpm.v6i1.866

Sudarman, Satrio Wicaksono, \& Linuhung, N. (2017). Pengaruh Pembelajaran Scafolding Terhadap Pemahaman Konsep Integral Mahasiswa. Aksioma Journal of Mathematics Education, 6(1). https://doi.org/http://doi.org/10.24127/ajpm.v6i1.866

Sun, J. C. Y., \& Hsu, K. Y. C. (2019). A smart eye-tracking feedback scaffolding approach to improving students' learning self-efficacy and performance in a $\mathrm{C}$ programming course. Computers in Human Behavior, 95, 66-72. https://doi.org/10.1016/j.chb.2019.01.036

Sun, Jerry Chih Yuan, \& Hsu, K. Y. C. (2019). A smart eye-tracking feedback scaffolding approach to improving students' learning self-efficacy and performance in a C programming course. Computers in Human Behavior, 95(April 2018), 66-72. https://doi.org/10.1016/j.chb.2019.01.036

Sunyono, \& Meristin, A. (2019). The Effect of Multiple Representation-Based Scaffolding Strategy in Improving Chemical Literacy. Jurnal Pendidikan Progresif, 9(2), 163-175. https://doi.org/http://jurnal.fkip.unila.ac.id/index.php/jpp/

Tri Astuti, R., \& Marzuki, H. (2018). Analisis Kesulitan Pemahaman Konsep Pada Materi Titrasi Asam Basa Siswa Sma. Orbital: Jurnal Pendidikan Kimia, 1(1), 22-27. https://doi.org/10.19109/ojpk.v1i1.1862

Yohana, I., Sudarmin, S., Wardani, S., \& Norashikin, S. (2018). The generic science skill profile of fourth grade students on acid and base topic in guided inquiry learning model. International Journal of Active Learning, 3(2), 110-116. https://doi.org/https://www.learntechlib.org/p/208673/

Yuliana, I., Kusairi, S., Taufiq, A., Priyadi, R., \& Rosyidah, N. D. (2020). The Analysis of Students' Problem-Solving Ability in the 5E Learning Cycle with Formative EAssessment. The 3rd International Conference on Mathematics and Sciences Education (ICOMSE.

Zainuddin, N., Sahrir, M. S., Idrus, R. M., \& Jaafar, M. N. (2016). Scaffolding a conceptual support for personalized arabic vocabulary learning using augmented reality (ar) enhanced flashcards. Journal of Personalized Learning, 2(1), 102-110.

Zamahsari, G. K., Roffi'uddin, A. H., \& HS, W. (2019). Implementasi Scaffolding dalam Pembelajaran BIPA di Kelas Pemula. Jurnal Pendidikan, 4(1), 68-78. https://doi.org/10.17977/jptpp.v4i1.11860 